\title{
Island Communities and Biotechnology
}

\author{
Edgar J. DaSilva ${ }^{1}$ \\ Director Section of Life Sciences Division of Basic Sciences UNESCO \\ 1, Rue Miollis, 75015 Paris France \\ E-Mail :e.dasilva@unesco.org \\ Mary Taylor \\ Regional Tissue Culture Adviser, Pacific Regional Agricultural Programme \\ University of the South Pacific Apia Western Samoa \\ fax: 0685-27035/22933
}

In the run-up to the year 2000 and beyond, several island countries, especially in the Caribbean and Pacific regions, are confronted by the challenges and threats of globalization. In response, several island countries are initiating self-reliant strategies aimed at national and regional endogenous development. Amongst these strategies, the potential of biotechnology for economic development and technological growth is being tapped.

The seas have long been used by island nations for the procurement of food and energy, for transport and communication, for political manoeuvre and military engagements, and as the inspiration for literature and art. Covering 71 per cent of the planet's surface, the world ocean is one continuous expanse of watery habitat for a rich diversity of flora and fauna ranging in size from the submicroscopic to the visible. In this biosphere or laboratory of Nature, the organisation and symphony of multiple natural systems vary from the simple to the complex, from the silent to the audible, and from the colourless to the nuanced tints of a Han Dynasty landscape, or again to the vivid and vibrant hues of a Van Gogh or Rembrandt.

Colwell (1987) recommends that islands and riparian nations explore the potential or marine biotechnology unique to their regions. Marine pharmaceuticals, genetic engineering of marine and estuarine animals and plants for food production, and marine speciality chemicals offer prospects for immediate and long-term rewards for island countries. Marine biotechnology is a subset of different biopractices such as aquaculture, marine natural products, bioremediation, cell culture, biosensors, and public health. The very use of these terms indicates the advances made through the use of spectacular biotechniques when one reflects on documentation of marine algae that have traditionally been used as food for humans, fodder for domestic animals, biofertilizer in agriculture and as sources of useful chemicals and medicines, and of energy and plastics (Lembi and Waaland, 1988). To sustain such marine bioindustries, species of red algae (Porphyra tenera) and brown entities (Undaria, Laminaria and Macrocystis) have been maintained in kelp ocean farms pioneered by the Japanese.

A large number of island communities in the developing world lie in rural or semi-urban areas where agriculture and aquaculture are the main economic activities. The application of biotechnology to these two scientific "cultures" would to a very large extent help revolutionize traditional practices into self-sustaining market ventures that could generate badly needed capital (DaSilva, 1998).

Contemporary research in Asia, Latin America and Africa has already led to the widespread use of the techniques of tissue culture and genetic engineering in maintaining export markets and creating new ones. Current efforts in the Caribbean and Pacific regions are indicative of this growing trend.

\section{The Caribbean}

The Caribbean nations consist of more than 25 island states with varying populations that depend on a rich diversity of plant genetic resources for their nutrition, health and wellbeing.

The plan "Caribbean Development to the Year 2000: Challenges, Prospects and Policies" emphasized the general absence of innovation in Caribbean industry. The acquisition of appropriate technology from abroad, and the development of a well-defined infrastructure to sustain such technology are identified as effective strategies in responding to these inherent weaknesses. Still again, many Caribbean countries with their island economies based on terrestrial and marine resources are encouraged to reconcile the sustained and judicious development of these resources with climatic and environmental changes. To meet these challenges, and to capitalize on the potential wealth of their resources, several Caribbean island countries have resorted to the systematic application of biotechnology.

One such step has been the establishment of a Caribbean Biotechnology Network, within the framework of UNESCO's global network of Microbial Resources Centres (MIRCENs) which resulted from political commitment when, a decade ago, the Grenada National Commission for UNESCO, representing the general agreement of Caribbean Ministers responsible for UNESCO Affairs and the Member States in the Caribbean sub-region, resolved that "an extension of the international network of resources centres (MIRCENs) be created in the Caribbean region". Another step forward resulted from action in the workshop "Perspectives for Biotechnology in the Caribbean, held in Port of Spain , Trinidad \& Tobago, February 1988, which 
articulated a regional strategy focusing on the following priority areas:

- micropropagation and tissue culture of plants

- integrated pest management

- nitrogen-fixation, enzymology and germplasm conservation

- antisera and diagnostics

- sugar industry fermentations, and

- embryo transplant technology

To date, the most common application of biotechnology in the Caribbean islands has been in the fermentation of rum and beer. More recently, tissue culture has been used as an economical tool for the micropropagation of many food and ornamental plants (Table 1). Another recent development is research into methods for food preservation and extension of the shell-life of plant products. The Mona and St. Augustine campuses of the University of the West Indies are involved in joint ventures. For example, the Jamaican Government collaborates with industry in the production of white potatoes, ginger, banana, and yam. In Trinidad, gingerlilies, roses and orchids are produced for local markets. Recently, the technique of embryo transfer has being used to boost meat and milk production. In general, microbial biotechnological practices in the islands of the Caribbean are:

- Production of citric acid from molasses

- Fermentation of sorghum for food and feed

- Uses of waste yeast from the fermentation industry

- Use of VA Mycorrhyzae to increase vegetable and legume crop yield

- Development of legume inoculant

- Molecular approach to studying bacterial blight disease in anthurium

- Recycling agricultural wastes for the production of animal feed and organic fertilizer

- Use of microbes in animal feed as a substitute for antibiotics.

The banana producing and exporting states in the Caribbean region-- Belize, Dominica, Grenada, Jamaica, St. Lucia, St. Vincent and the Grenadines, and the Windward Islands, are plagued by a variety of geographical and economic disadvantages that are uncommon to their Central and South American competitors. Hilly terrain and hurricane-exposed locations add to high management and shipping costs of smaller volumes of banana exports. Crop production on steep terrain and small family venture farms, e.g. in the Windward Islands, continues to be the backbone of several rural economies and the socio-political fabric of a number of the Caribbean island countries. Collapse of such economies, can lead to socio-political turmoil, decimation of the tourist industry, to an exodus of economic refugees, development of undesirable markets e.g. illegal drug trade, and to turbulence and weakening of interdependent socio-economic infrastructures such as CARICOM and the Caribbean Basin Initiative.
Maconellicoccus hirsutus, also commonly known as Hibiscus Mealy Bug or Pink Mealy Bug (PMB) is a new pest that, since 1993/1994, has been recorded in the Caribbean isles. Economic losses resulting from infestation of over 125 plant species, inclusive of beverage and food crops, fruits, vegetables, forest species, and ornamental plants have been severe in the region. In Grenada alone, it has been estimated that over US\$50 million have been lost during 1993/1994, and that about 15,000 farm enterprises have been wiped out as a result of attack by PMB. The spread of the infestation has now been reported in Trinidad and Tobago, St. Lucia, St. Kitts and Nevis, St. Vincent and the Grenadines, and the Windward Islands.

Fungal and bacterial diseases have also been identified as significant factors in economic losses of spoilt banana exports and vegetables. Viral diseases, borne by the white fly Bemisia tabaci, are responsible for severe economic losses arising from damage to melons, sweet potatoes, tomatoes and aubergines. The pest, first encountered in the Caribbean region in the mid-1970s, has contributed to estimated losses of US\$50 million p.a. in the Dominican Republic.

In the framework of joint UNDP/UNESCO collaboration on the application of science and technology for development in the Caribbean, research has been carried out on the control of bacterial spot of pepper and tomato caused by Xanthomonas campestris var. vesicatoria (O'Garro, 1997)

The Organization of the Eastern Caribbean States (OECS), which promotes economic integration and encourages export security in small island countries is composed of Member States - Antigua and Barbuda, Dominica, Grenada, St. Kitts and Nevis, St. Lucia, and St. Vincent and the Grenadines. These island states on account of their monocrop economies, fragile ecosystems, location in the hurricane belt between the Atlantic Ocean and the Caribbean Sea, and little size, are extremely vulnerable to the forces of globalized development. The El Nino phenomenon also has a negative impact on crop production in the Caribbean isles. According to the global information and early warning system on food and agriculture, seasonal cereal and bean crops bosses for 1997 have been estimated at about 20 per cent in several Central American and Caribbean countries. Similar loss risks are anticipated in 1998.

Shock waves have been witnessed in most of the OECS banana-producing countries as a result of the hurricane storms in 1994 and 1995, and still again by the possible loss, after 2001, of European economic preferences for Caribbean bananas. It is estimated that 4000 to 8000 small farmers, in especially Dominica, St. Lucia, and St. Vincent and the Grenadines, may have to exit the banana industry and reinvest in other ventures. In this regard, cultural tourism seems to be a dominating option. Other options for diversification of agricultural markets are to be found in the cultivation of okra, tomatoes and avocados. On the negative side, the allure of easy revenue makes the illegal cultivation of marijuana an attractive proposition despite the risks involved.

Biomethanation programmes in the island states of the Caribbean region have been supported by the Caribbean 
Development Bank. Jamaica, with funding from the Latin American Energy Organization (OLADE) has been particularly active in experimenting with a variety of biodigester designs and models (Clancy and Hulscher, 1994).

Caribbean regional health issues and health-care reforms have benefited from IDB/PAHO ${ }^{\circ}$ collaboration and the Consultative Group for Caribbean Economic Development (CGCED). Demographic, socio-economic and health indicators in participating countries - Antigua and Barbuda, the Bahamas, Barbados, Belize, Dominica, the Dominican Republic, Grenada, Guyana, Haiti, Jamaica, St. Kitts and Nevis, St. Lucia, St. Vincent and the Grenadines, Trinidad and Tobago, and Suriname, emphasize the need for reducing preventable diseases, and for developing health welfare programmes for aging populations and geriatric diseases. Upward trends have been identified in communicable diseases such tuberculosis and HIV/AIDS, in nutritional deficiencies, and in the re-emergence of malaria, cholera and dengue fever.

\section{The Pacific}

Over the past decades, about 27 nations with thousands of islands in the Pacific region have emerged with aid through the South Pacific Commission. Like that of the Caribbean, the Pacific region is dependent on a remarkably fragile environment, characterized by limited natural resources, including land, and a high incidence of natural disasters. Traditional cultures have emphasized, unknowingly, environmental management in the Pacific island communities which are confronted daily with the impact of the consumer age, industrialization and, in some areas, unprecedented population growth. The challenge, these nations face today, is to find a balance between conservation and development of the region and its environment in the interests of bettering the quality of life of the Pacific peoples through appropriate scientific programmes. The Pacific region has two major universities, the Papua New Guinea University in Port Moresby and the University of the Southern Pacific with its main campus in Suva, Fiji and a smaller component in Apia, Western Samoa.

The nations of the Pacific region share scientific and technological concerns peculiar to their geographic and oceanographic characteristic. They frequently face substantial constraints in terms of scientific, technological, managerial, and economic resources necessary for sustainable, island-wide, maricultural and maritime development. The most important of such developmental and educational issues are microbial aspects related to human health, nutrition, food safety and energy supply.

With the help of the Australian National Commission for UNESCO, Massey University and Cawthron Institute in New Zealand and the government authorities of many of the Pacific island nations, a survey, a decade ago by the MIRCEN at the University of Queensland, Brisbane, established that some 50 researchers from 19 countries in

\footnotetext{
- International Development Bank/Pan-American Health Organization
}

over 44 laboratories were desirous of collaborating with each other in the following areas:

- agricultural biotechnology ranging from plant improvement to agro-processing and soil fertility;

- biodegradation;

- fermentation ranging from the production industrial alcohol to food, feed, and fertilizer

- treatment of wastewaters

- microbial product formation

- aquaculture from algal production to fish breeding and cultivation within the framework of a Pacific MIRCEN biotechnology network.

At face value, these requirements could be easily met by a transfer of existing microbial technology or the design and development of new appropriate microbial processes (Doelle 1989). However, everyone of these areas requires an infrastructure which is just not available in the Pacific Region. Nevertheless, in a pioneering effort, a Pacific MIRCEN workshop in Fiji on "Agricultural Development in the Pacific Islands in '90" made clear that:

a) there is an almost complete lack of trained biotechnologists in the Pacific region;

b) none of the three universities have a Department of Microbiology nor a degree course in this subject;

c) fermentations, determination of water quality, and waste disposal control are carried out mainly by biologists or engineers, who have only sparse or marginal knowledge of microbiology or biotechnology

d) the availability of arable land, climatic conditions, the high standard of plant breeding, and plant culture improvement research reveals the potential for agricultural biotechnology, socio-ecological and aquacultural (algae) biotechnology;

e) the use of algae in place of chemically-based nitrogen fertilizers and as fish food in the Pacific island states;

f) the strengthening of mushroom production in Tonga, and the use of Rhizobium inoculants in Western Samoa.

The South Pacific region is composed of a vast number of islands that vary in size from Papua New Guinea with a population of around four million, to Nuie with a population of 2,000. The diversity of plant genetic resources and the availability of other resources such as labour varies though the latter, as a general rule, is always a limiting factor in agricultural production. Daily subsistence is mainly based on agriculture, though some of the islands have adopted a more commercial approach for export purposes. This is the case in Tonga with its production of squash for the Japanese market. Generally-speaking the crops grown throughout the Pacific region are mostly root and tuber crops, banana, and coconut (Table 1).

At the moment, the only real application of biotechnology in the region is tissue culture. It was first introduced into the region through the tissue culture laboratory established by the South Pacific Commission (SPC), Plant Protection Service in Fiji with the aim of increasing the number of varieties of the main root and tuber crops available in the Pacific island countries, and to facilitate their distribution 
through their pathogen-tested status. In the late 1980s another tissue culture laboratory was established on the campus of the University of the South Pacific (USP), Western Samoa to provide security for the germplasm material that was being maintained in Suva, Fiji. This duplicate collection, also enables the distribution of pathogen-tested material, and the facility, where possible, provides training and research services. In 1990, funding from the European Union established the Pacific Regional Agricultural Programme (PRAP) which is comprised of a number of projects based in eight Pacific countries that are amongst the African-Caribbean-Pacific (ACP) group of countries covered by the Lomé Convention.

PRAP has been active in the region for seven years, with Phase 1 being completed in 1994. In Phase 1 the aims and objectives of the tissue culture project, located at USP, Apia, Western Samoa, were: the introduction of tissue culture methods for crops important in the region; the provision of germplasm storage for regional crops and the multiplication of traditional and improved varieties important to the region. In order to achieve these results, the unit at USP was modified from a one-room unit to a four-room facility, inclusive of two growth rooms; each with a capacity of 5,000 to 10,000 cultures. One growth room is maintained at a reduced temperature for germplasm storage. Furthermore, a new aphid-proof screenhouse was built with a capacity of 1,000 to 3,000 plants, so that pathogen-tested material could be weaned and maintain their pathogen-tested status. During Phase 1 training of regional staff was an on-going process through workshops, in-depth attachments, and Master degree programmes. Whereas research in the initial seven-year period, concentrated on optimising tissue culture methodology for the more staple root and tuber crops, and developing systems for new crops, e.g. Abelmoschus manihot (bele), on-going training programmes also provided opportunities for in-depth internships and postgraduate formation.

Phase 2 of PRAP starting in 1994, changed the emphasis from focusing on a regional facility to that of developing the national capabilities of the non-atoll PACP countries (Vanuatu, Solomon Islands and Fiji) in tissue culture technology; and, strengthening the existing national tissue culture laboratories in Western Samoa, Tonga and Papua New Guinea. The task of PRAP was to resolve bottleneck problems through the provision of equipment, training and technical support. Furthermore, the effective functioning of the national tissue culture laboratories as self-reliant and selfsufficient genebanks, would provide planting material to local growers, thus guaranteeing food security, conservation of plant genetic resources and offer source of ornamental germplasm of export significance. Laboratories now exist in all the non-atoll PRAP countries. Though most of the national laboratories focus on the production of crop plants, the national laboratory at the Nu'u research station in Western Samoa produces orchids and anthuriums for the local market.

As with field genebanks throughout the world, losses are occurring at an ever-increasing rate in the South Pacific. Most of the information, on field conservation, which is available for the South Pacific island countries relates to taro and yams. Jackson (1994) recently examined collections of taro and yams established in the 1980s in nine Pacific island countries (Table 2) and found that significant losses have occurred. These have resulted from lack of finances for costly maintenance; inadequate storage facilities, contamination and infection with plant pathogens, and improper protection against cyclonic and drought conditions.

In the PRAP regional laboratory in Western Samoa, except for cassava, all the taro, yam, sweet potato and banana collection are maintained at a reduced temperature $\left(20^{\circ} \mathrm{C}\right)$. In collaboration with IPGRI, the laboratory in Apia, at the University of the South Pacific, is involved in a global experiment on in vitro slow growth storage of sweet potato. This project, which initially involved the Pacific and Caribbean regions, and now includes the Philippines, Vietnam and China, aims:

- to develop/reinforce expertise on in vitro culture/slow growth storage of sweet potato in the Asia-PacificOceania (APO) and Caribbean regions;

- to assess the efficiency and flexibility of common in vitro slow growth protocols in different technical environments and;

- to develop/strengthen links and interactions between in vitro culture laboratories within and between the APO and Caribbean regions.

Another area of concern in the South Pacific islands is that of intellectual property rights. The PRAP tissue culture projects first became involved with the issues of intellectual property rights on account of requests from a commercial tissue culture laboratory, outside the Pacific island region for taro germplasm and the relevant multiplication technology (Taylor, 1996). The issue of germplasm exchange that aroused regional interest and concern, has led to the consideration of emerging pressures which emphasise the need for the Pacific island countries to consider some form of intellectual property rights system:

These pressures are:

- The need to comply with the directives of the World Trade Organization to its members to institute a system of plant variety protection either through the use of patents or an 'effective sui generis system' by 1999;

- Increased bioprospecting in the Pacific island region, that is being practised often without prior informed consent and mutually agreed terms between the bioprospectors and the country in possession of the desired resources; and

- Imminent loss of commercial markets of medicinal plants such as kava that are of significance in the pharmaceutical industry.

On the issue of genebanks, the regional laboratories in the South Pacific, are responsible for a wide range of crop germplasm originating from many different island countries in Polynesia, Melanesia and Micronesia. These collections were originally assembled on the principle of 'common heritage' in the absence of a defined policy regarding germplasm exchange. Today, with the galloping advances being made in deriving benefits from the applications of 
biotechnology, the Pacific island countries have become concerned about the possible patenting of their plant and microbial genetic resources.

What type of biotechnology development is therefore appropriate to the Caribbean and Pacific Regions? In response, the national economic and social objectives have been identified (FAO, 1992). These deal with the achievement of sustainable growth in the commercial production of quality agricultural products for domestic consumption; and the development of appropriate regional strategies that help to counteract the import-oriented markets that cripple the economies of these regions. These strategies are also of relevance to islands in the Asian and African environments. In the run-up to the new millennium, it is anticipated that all of the tissue culture laboratories in the six non-atoll PACP countries will be functioning well, producing planting material for growers, assisting in the safe importation of plants and conserving some of the region's most important genetic resources. It is hoped that all countries outside of PRAP will also be active in tissue culture, for example Kosrae, American Samoa. To satisfy the demand of a much needed regional service collection, the Oceania plant tissue culture network has been established to ensure regular opportunities for voice, data and increasingly video communications between over 40 sites in the Pacific islands nations through the Pacific Education and Communication Experiments by Satellite (PEACESAT) which is managed by the University of Hawaii in Honolulu. The network also produces a quarterly newsletter with contributions from all members. The feasibility of establishing a regional centre dealing with virus testing, molecular technology, identification of microbial plant pathogens, biocontrol of insects, etc., is seriously being considered. A start has already been made in the area of health care. National networks on occupational safety and health information have been established in small island countries of Fiji and the Solomon Islands. The Occupational Safety and Health Information Centre (CIS) based in Honiara, functions as an international node in the global network on occupational safety and health, jointly sponsored by ILO/FINNIDA

The South Pacific Forum (SPF) established in 1971 as a forum of the governments of the South Pacific-- Australia, Cooks Islands, Fiji, Kiribati, Nauru, New Zealand, Niue, Papua New Guinea, Solomon Islands, Tonga, Tuvalu, Vanuatu, and Western Samoa, to discuss and implement issues of economic and technical interest has already promoted regional co-operation in fields such as:

- Bioenergy production in Fiji, Cook islands, Guam, and Papua New Guinea;

- Development of aquaculture in the University of the South pacific in Suva, Fiji; the Centre Oceanologique du Pacifique, Tahiti (French Territory); in the Department of Fisheries in Alopi, Niue; Micronesia in Aquaculture Research Centre, Micronesia;

\footnotetext{
- International Labour Organization/Finnish International Development Agency
}

- Development and use of plant tissue culture at: the Sugarcane Research Centre, Lautoka, Fiji; the Dodo Creek Research station, Honiara, Solomon Islands; and the Forest Research Institute in Port Moresby, Papua New Guinea;

- Reliance on microbial biotechnologies such as fermented foods, BNF, biocontrol, waste management and algal culture throughout the region.

Furthermore, SPF has contributed to the development of, and now, serves as the depositary of the Convention to Ban the Importation into Forum Island Countries of Hazardous and Radioactive Wastes and to Control the Transboundary Movement and Management of Hazardous Wastes within the South Pacific Region (Waigani Convention).

More recently, SPF has been active in the implementation of the South Pacific Regional Environmental Programme (SPREP) for 1997 - 2000 following its adoption in Nuku'alofa, Tonga in December, 1996. Amongst other issues, SPREP deals with the conservation of biological diversity; coastal zone management; and waste management.

\section{Conclusion}

Despite their fragile economies aspects that are also characteristic of Asian and African small islands (Table 3), and their vulnerability to the vicissitudes of Nature, very few of the Caribbean and Pacific islands are encountered in the category of the least developed countries (Table 4). The new millennium will bring with it the graduation of Samoa from the list.

Globalization has embraced the world of islands in Asia, Africa, Europe, the Caribbean and the Pacific regions. As a result, and despite the geographic and economic limitations that slow down the pace of technological advancement, several island nations have embarked upon the path of diversifying and modernising their reliance on traditional agricultural and Nature-given biotech resources. Amongst the various options, virtually all island countries, inclusive of Cyprus and Malta, have adopted high-tech biotechnology, genetic-engineering, and gene-rich microorganisms as strategic mechanisms in ensuring self-reliant development and economic stability for the year 2000 and beyond.

\section{References}

Clancy,J.S. and Hulscher, W.S. (1994). The possibilities of biogas production in developing countries. Special programme for biotechnology development co-operation. Directorate-General for International Co-operation, Ministry of Foreign Affairs, The Hague, Netherlands.

Colwell, R.R. (1987). Marine biotechnology and the developing countries. In: Microbial Technology for developing countries, Eds. DaSilva, E.J. et al, Oxford University. Press Oxford, UK, pp. 151-166.

DaSilva, E.J. (1998). Biotechnology: Developing Countries and Globalization. World Journal of Microbiology and Biotechnology. 14 (in press). 
Doelle, H.W. (1989). Socio-economic biotechnology development for developing countries. MIRCEN Journal of Applied Microbiology and Biotechnology. 5: 391-410.

Jackson G.V.H. (1994). Taro and Yam resources in the Pacific and Asia, Report for ACIAR and IPGRI, Anutech Pty., Ltd

Lembi, A. and Waaland, J.R. (1998). Algae and Human Affairs, Cambridge University Press, London, pp. 590

O'Garro, L. (1997). Prospects for Control of Bacterial Spot of Pepper and Tomato in the Anglophone Eastern Caribbean: A Research Model for the Application of Biotechnology in Small Developing Countries, UNESCO, Port of Spain, pp. 99
FAO, (1992). Current Status and Future Prospects of Modern Biotechnologies in Latin America and the Caribbean. Executive Summary 22nd Regional Conference for Latin America and the Caribbean, 28 September - 2 October, Montevideo, Uruguay. Document LARC/92/4 W/Z9328/c.

Taylor M. (1996) Intellectual property rights and plant germplasm in the South Pacific region. PRAP Working Paper No. 96-3. Suva: Pacific Regional Agricultural Programme (PRAP). Project 7. Provision of tissue Culture Services for the Region.

Table 1. Biotechnology activities in the Caribbean and Pacific islands

\section{Country}

Bahamas

Barbados

Belize

*Cook Islands, Fiji, Kiribati, Niue, Samoa, Solomon Islands, Tokelau, Tonga, Tuvalu and Vanuatu

Cook Islands, Fiji, Tonga, Samoa, Vanuatu, Solomon Islands and Federated States of Micronesia (FSM)

Dominica

Dominican Republic

FSM, Kiribati, Tuvalu

Fiji

Fiji, Kiribati, Solomon Islands

Fiji, Solomon Islands and Vanuatu
Eleuthera isle, the "bread basket" of the Bahamas is a major supplier of bananas, citrus and pineapples. The Ministry of Agriculture supports development of tissue culture facilities to assist in mass production of citrus fruits and root crops, and to conserve and produce native orchids and floristic ornamentals

- Tissue culture programmes in the improvement of the yam species Discorea alata started in 1979 with emphasis on maintaining the market value of the cultivar White Lisbon that was being eroded by a viral disease - Internal Brown Spot. Today, over 1 million kilograms of planted materials are distributed to farmers in 11 CARICOM countries. A $40 \%$ increase in crop yield has been obtained with the use of "clean" planting material.

- Development of vesicular-arbuscular mycorrhizae (VAM) inoculants for use with red kidney beans (Phaseolus vulgaris), Winged bean (Psophocarpus tetragonolobus), and moth bean (Vigna aconitifolia)

Ministry of Agriculture developing improved planting material of cassava, yams, coconut, and bioconversion of crop residue into livestock and shrimp feed. Belizean technical staff being trained at Centro Agronocquo de Investigacion Esperanza (CATIE), Costa Rica

Distribution of vaccines, and development of monitored regional immunization programmes to control the spread of Hepatitis $B$ in infants and young children, and to reduce the impact of long-term liver disease. This Hepatitis $B$ project is sponsored by UNICEF and the governments of Australia and New Zealand

Establishment of regional fruit fly project to control and eradicate fruit fly infestation in fresh fruits and vegetables; implementation of plant protection measures, and provision of quarantine expertise

Tissue culture biocontrol measures have been employed in a CARDI developed techpak kit to contain and eliminate the outbreak of Leaf Burning Disease caused by the fungus Pythium myriotylum in cocoyam (tannia) Xanthosoma sagittifolium

- Global Environment Fund (GEF) project dealing with the identification, inventorization, cultivation and use of medicinal plants in co-operation with the Sociedad Ecologia de Oveido

- GEF project involving alternative models for production of biogas; Fundacion Nacional para el Desarollo de la Juventad Rural, Inc. (FUNDEJUR) supporting project on producing biogas from swine-herd wastes processed by 10 biodigestors.

Biological control of breadfruit mealy bug in the Pacific

Sustainable and strategic control of gastrointestinal parasites of ruminants using urea-molasses blocks

Pacific Island pearl oyster resource development

Vector Borne Diseases Control project to eradicate mosquitoes-borne diseases - malaria, dengue fever and filiariasis that are a major health problem in the Pacific 
Grenada

Guyana

Jamaica

Kiribati

Kiribati, Solomon Islands, Tuvalu

New Caledonia

Pacific Islands

Papua New Guinea

Samoa

St. Kitts and Nevis
- The banana industry is one of the major mainstays of the Grenadian economy. The industry contributes about 3 per cent of the gross domestic product. A tissue culture facility, since 1992, exists at Mt. Whaldeal, St. George, to control and contain the spread of Moko disease, and eradicate the causative agent Pseudomonas solanacearium. Over 4000 plantlets per month are produced and distributed to banana growers. The European Commission /WINBAN Moko Disease Control programme has been designed to reinforce the activities of the planted producing facility, and to prevent the spread of the disease to the Windward Islands.

- Producer of $25 \%$ of the world's exports of nutmeg and mace (Myristica fragrans)

- The National Agricultural Research Institute (NARI) in collaboration with FAO, is engaged in the production of shoots from dormant axillary buds of pineapple (Ananas comosus L. Marr.). About 8000 plantlets of citrus fruits and tuber crops are produced p.a. for use by farmers.

- Distribution of tissue-cultured plantlets of sweet potatoes, plantains, cassava and pineapples to farmers for use in NARI station plot at Parika as part of national strategy to boost employment market and export sales.

- Producer of $25 \%$ of the world's exports of nutmeg and mace (Myristica fragrans)

- Scientific Research Council sponsors the Tissue Culture Research and Development (TCRD) project which deals with the production of virus-free planting material of the Irish potato Solanum tuberosum. Other TCRD activities deal with the micropropagation of ornamentals, food crops, and orchids. Amongst the food crops attention is given to the production of tissue-cultured planting material of yam species e.g. Dioscorea cayenensis, D. rotundata, D.alata and D. Trifida

- Development of culture protocols for the growth and multiplication of Heliconia varieties and other ornamentals such as orchids, Anthurium, and Leather Leaf Fern (Rumorha adiantiformis)

- Development of mushroom industry using oyster mushroom Pleurotus sajor-caju

- Tissue culture protocols for development and distribution of plantlets, for use by farmers, have been developed for: food and cash crops

- sweet potato (Ipomoea batatas)

- cassava (Manihot esculenta)

- dasheen (Colocasia esculenta)

- plantains (Musa spp)

- breadfruit (Artocarpus altilis)

- jackfruit (A. heterophyllus)

- carambola (Avevrhoa carambola)

- yam bean (Pachyrhizus erosus)

- cacao (Theobroma cacao)

- pineapple (Ananas comosus)

- sugarcane (Saccharum officinarum) and for cut-flowers and ornamentals:

- Aechmia nandicaulis

- Heliconia

- Mussaenda erythrophylla
- Alpinia purpurata (ginga lily-pink)

- Biocontrol of breadfruit mealy bug has been accomplished in the outer atolls

- Development of reef passages to fisheries resources in coral atolls of the Pacific

Biochemical analysis of tuna purse seining in Pacific Islands region

Prevention in the spread of HIV/AIDS and its impact on the Kanak population through communitybased prevention strategies and education in sexual behaviour

- HIV/AIDS prevention activities; prevention and treatment of lifestyle (non-communicable diseases) such as diabetes, hypertension and heart disease

- Delivery and supply of vaccines to the peoples of the Pacific through the UNICEF Vaccine Independence Initiative in collaboration with AusAID with focus on self-reliant funding rather than on changing donor priorities

- Cultivation of wild edible mushrooms and development of a culture collection at the University of Papua New Guinea in collaboration with UNESCO

- Brokenil orchid project, funded by GEF focuses on propagation of wild orchids on a communityowned farm in Simbu Province

- Use of spent brewers grains for composting. Locally known as molo, and in combination with chicken manure, the mix is employed as a conditioner in increasing the organic content and matter of soil substrates. Laboratory work carried out at Alafua Campus, University of the South Pacific in collaboration with UNESCO

The Ministry of Agriculture supports a major agricultural diversification programme that develops the production of non-sugar agriculture and marine biotechnology. This strategy whilst safeguarding against losses in the sugar exports market also helps complement ongoing basic tissue culture production of tuber crops. 
St. Vincent \& the Grenadines

Solomon Islands

Trinidad \& Tobago

Tonga

Vanuatu

\section{REGIONAL} CARDI**

- The Chinese Technical Mission has introduced tissue culture of yams and orchids.

- The French Technical Mission provides back-up assistance in developing greenhouse facilities

- The UNESCO Biotechnology Action Council has provided fellowship opportunities for training in Trinidad and Tobago

- Provision of support research on development of resistant pepper and tomato genotypes to bacterial spot disease caused by Xanthomans campestris var. vesicaloria

- Development of marine protected reserves for restoration and management of tropical multispecies fisheries

- Large-scale village grow out trials for giant clams

Plant tissue culture, with emphasis on the rapid propagation and improvement of crops of agricultural and horticultural economic importance in the region, has been pioneered by the Department of Plant Science, University of the West Indies, St. Augustine Campus. With OAS sponsorship, teaching and research programmes focus on:

(i) the development of protocols in monitoring the health and quality of plant germplasm of economically significant species, and

(ii) ensuring appropriate biocontrol and quarantine measures that aim at improving crop yields of yams. sweet potatoes, and cassava species. Activities are carried out in co-operation with FAO, UNESCO, UNDP, Ministry of Agriculture, CIAT, INRA and IITA

Sustainability of nutrient cycling in cropping and pasture systems; producer with Vanuatu of high value low bulk cash crop - vanilla (Vanilla planifolia)

Reef reseeding research of topshell Trochus niloticus in north Australia, east Indonesia, and the Pacific

The Caribbean Agriculture Research and Development Institute (CARDI) based in Trinidad and Tobago has been a pioneer in the development of plant biotechnology in the region. Established in 1975, CARDI provides appropriate agricultural research and development services to the Member States of the Caribbean Community and Common Market (CARICOM). Amongst its varied activities, priority is given by CARDI to the production of "clean" planting material of improved varieties. The CARDI tissue culture laboratory in Barbados, serves as a repository for virus-free yam material, and germplasm storage of selected crop species of economic significance. Moreover, a supply service of plantlets is made to several of the islands country members (See Table below)

Planting Material supplied by the tissue culture laboratory, Barbados

\begin{tabular}{|c|c|c|c|c|c|c|}
\hline Crop & Barbados & Grenada & $\begin{array}{l}\text { St. Kitts \& } \\
\text { Nevis }\end{array}$ & St. Lucia & $\begin{array}{l}\text { St Vincent \& } \\
\text { Grenadines }\end{array}$ & $\begin{array}{l}\text { Trinidad \& } \\
\text { Tobago }\end{array}$ \\
\hline
\end{tabular}

$\begin{array}{llllll}\text { Cassava } & \sqrt{ } & \sqrt{ } & & \sqrt{ } & \\ \text { Sweet potato } & \sqrt{ } & & \sqrt{ } & \sqrt{ } \\ \text { Yams*** } & \sqrt{ } & \sqrt{ } & \sqrt{ } & \sqrt{ } & \\ \text { Horticultural } & & & & \sqrt{ } \\ \text { Banana } & & & \sqrt{ } & \sqrt{ } \\ \text { Plantain } & \sqrt{ } & & & \end{array}$

* $\quad$ Projects of Australian Centre of International Agricultural Research ACIAR) in `partner countries in the pacific and in co-operation with the Australian Agency for International Development AusAID).

** Comprised of network institutes in several of the Caribbean islands countries

*** Food Species: Dioscorea alata, D. cayanensis, D. esculenta, D. rofundata, and D. trifida. Exports to Canadian markets amount to 2000 t.p.a.

**** Pacific Regional Agricultural Programme

Table 2: Taro and yam collections in Pacific island countries

Countries Number of Accessions in the Collections

\begin{tabular}{lcccccc}
\hline & Taro & & \multicolumn{2}{c}{ Dioscorea alata } & \multicolumn{2}{c}{ Discorea esculenta } \\
& 1985 & 1994 & 1985 & 1994 & 1985 & 1994 \\
\hline Cook Islands & 57 & & 8 & 3 &
\end{tabular}




\begin{tabular}{|c|c|c|c|c|c|}
\hline Fiji & 72 & 78 & 89 & 75 & 16 \\
\hline Niue & 52 & & 23 & & \\
\hline Laloki, PNG & 135 & & 153 & 167 & 94 \\
\hline Bubia, PNG & 120 & 450 & 153 & & 94 \\
\hline Solomon Is. & 31 & 2 & 238 & 55 & 117 \\
\hline Tonga & & 21 & & & \\
\hline Tuvalu & 13 & 13 & & & \\
\hline Vanuatu & 138 & & 194 & $?$ & 17 \\
\hline MAFFM*, WS & 20 & 17 & & & \\
\hline USP, WS & 28 & & 12 & & 2 \\
\hline
\end{tabular}

* Ministry of Agriculture, Fisheries, Food and Meteorology

Table 3: Some biotechnological initiatives in African, Arab, Asian and European islands

\section{Island Major Food Crops Specific characteristics}

Bahrain Dates, pisciculture

Cape Verde Maize, rice, pulses

Comoros

Madagascar

Rice, roots, tubers, maize,

fruit Vanilla, cloves

(Syzygium aromaticum

Rice, tubers, roots, bananas and coconuts

Vanilla

Potatoes, vegetables, grapes

Cyprus
- Desert biotechnology, arid zone biology

- Coastal and marine biotechnology

- Low-income food-deficit country

- Crop productivity prone to damage due to onset of grasshopper infestations

Archipelago of 4 small islands

- Low-income food-deficit country barley, olives, citrus fruits

The World Bank "graduated" Cyprus off the list of developing countries in June 1991

Maldives
Fruits, vegetables
Low-income food-deficit country 

Malta $\quad \begin{aligned} & \text { Pisciculture, vegetables, } \\ & \text { animal husbandry }\end{aligned}$

Bananas, breadfruit and cocoyam

Principe

Seychelles
- Amongst the 17 Smallest Countries

- shares advantages of established key small island economies around the world - Hong Kong, Singapore, Channel Islands

- Low-income food-deficit country

- Consists of 100 islands scattered over 1 million sq.km.

- 50 per cent of gross domestic revenue derived from tourism
- Agriculture accounts for $2 \%$ of the work force and $20 \%$ of selfsufficiency in the sector

- Diversification into high biotech research - biopharmaceuticals

- Cereals imported annually for human consumption

- In need of food-aid programmes

- Cultivated area of about 10,000 hectares used for coconuts, fruits, vegetables and livestock

- Cereal food and feed needs completely imported

\section{Table 4: Chronological and historical background: least developed countries}

$\frac{\text { Year }}{1971}$

$\overline{1971}$

1975

1977

1981

1982

1985

1986

1987

1988

1990

1991

1994

\section{Countries}

Afghanistan, Benin, Bhutan, Botswana', Burundi, Chad, Ethiopia, Guinea, Laos, Lesotho, Malawi, Maldives ${ }^{2}$, Mali, Nepal, Niger, Rwanda, Somalia, Sudan, Uganda, Tanzania, Upper Volta ${ }^{3}$, Samoa $^{2}$ and Yemen Arab Republic

Bangladesh, Central African Republic, Democratic Yemen, Gambia

Cape Verde ${ }^{2}$, Comoros

Guinea-Bissau

Djibouti, Equatorial Guinea, Sao Tome and Principe, Sierra Leone, Togo

Vanuatu $^{4}$

Kiribati, Mauritania, Tuvalu

Myanmar $^{5}$

Mozambique

Liberia

Cambodia, Madagascar, Solomon Islands, Zaire ${ }^{6}$ and Zambia

Eritrea and Angola

\footnotetext{
${ }^{1}=$ The only LDC to graduate from the list into the Category of Developing Countries after 25 years (1996)

${ }^{2}=$ Recommended for graduation from the list in 2000

$3^{3}=$ Now Burkina Faso

${ }^{4}=$ Recommended for graduation on 31 December 1997

5 = Formerly known as Burma

${ }^{6}=$ Now Republic of Congo
} 